\title{
Splice-Site Mutation
}

National Cancer Institute

\section{Source}

National Cancer Institute. Splice-Site Mutation. NCI Thesaurus. Code C19798.

Any mutation that occurs within the discrete sequences comprising the $5^{\prime}$ or $3^{\prime}$ splice sites of a gene that has a spliced message. Splice-site mutation may result in a deletion or insertion of extraneous amino acids in the gene product or a change in the reading frame of the spliced message. 